\title{
The potential of indigenous bacteria from oil sludge for biosurfactant production using hydrolysate of agricultural waste
}

\author{
NI'MATUZAHROH ${ }^{1, \boldsymbol{v}}$, SILVIA KURNIA SARI ${ }^{1}$, IRINE PUSPA NINGRUM ${ }^{1}$, APRILLA DILA PUSFITA ${ }^{1}$, LISA \\ MARJAYANDARI ${ }^{1}$, NASTITI TRIKURNIADEWI ${ }^{1}$, SYAHRIAR NUR MAULANA MALIK IBRAHIM ${ }^{1}$, \\ FATIMAH $^{1}$, TRI NURHARIYATI ${ }^{1}$, TINI SURTININGSIH ${ }^{1}$, HANIF YULIANI ${ }^{2}$ \\ ${ }^{1}$ Department of Biology, Faculty of Science and Technology, Universitas Airlangga, Kampus C Mulyorejo Surabaya 60115, East Java, Indonesia. \\ Tel.: +62-31-5936501, Fax.: +62-31-5926804. `email: nimatuzahroh@fst.unair.ac.id \\ ${ }^{2}$ Agency for The Assessment and Application of Technology. Jl. Raya Puspiptek, Serpong, Tangerang Selatan 15311, Banten, Indonesia.
}

Manuscript received: 31 January 2019. Revision accepted: 26 April 2019

\begin{abstract}
Ni'matuzahroh, Sari SK, Ningrum IP, Pusfita AD, Marjayandari L, Trikurniadewi N, Ibrahim SNMM, Fatimah, Nurhariyati T, Surtiningsih T, Yuliani H. 2019. The potential of indigenous bacteria from oil sludge for biosurfactant production using hydrolysate of agricultural waste. Biodiversitas 20: 1374-1379. Biosurfactants are amphipathic compounds which are useful in various fields of health, industry, and remediation. Biosurfactants are produced by bacteria that grow in hydrocarbon or sugar substrates. Hydrolysis product of agricultural waste can be used as a biosurfactant production medium. This research aims to obtain biosurfactant producing bacteria from Balongan oil sludge, Indonesia. The ability to grow and produce biosurfactant by indigenous bacteria was tested using a medium of Synthetic Mineral Water (SMW) added by $209.3 \mathrm{ppm}$ of rice straw hydrolysis product (RSHP). The growth of bacteria was evaluated through Total Plate Count (TPC) and biosurfactant production was evaluated through measurement of emulsification activity and surface tension. Six indigenous bacteria were capable to produce biosurfactants in the RSHP. Emulsification activity was not detected, but surface tension reduction was founded. The best biosurfactant was indicated by surface tension value of $53.56 \mathrm{mN} / \mathrm{m}$ with TPC value of $20.07 \mathrm{CFU} / \mathrm{mL}$ at the $5^{\text {th }}$ day of incubation by BP (1) 5. The indigenous bacteria were identified as Propionibacterium BP (1) 1 , Propionibacterium BP (1) 3, Bacillus BP (1) 4, Corynebacterium BP (1) 5, Corynebacterium BP (1) 8, and Rothia BP (1) 6. Utilization of sugar as hydrolysis product of agricultural waste is an innovation of raw materials for biosurfactant production.
\end{abstract}

Keywords: Agricultural waste, biosurfactant, indigenous bacteria, oil sludge, rice straw

\section{INTRODUCTION}

Biosurfactants are amphipathic compounds which are useful in various fields of health, industry, and remediation. Biosurfactants have low toxicity, easy manufacture, and wide application (Elazzazy et al. 2015). Biosurfactants are produced by bacteria that grow in hydrocarbon environments and can be secreted on the surface or outside cells in growth media with noticeable by surface tension reduction and emulsifying activities. (Kosaric 1993). Biosurfactant contains hydrophobic and hydrophilic molecules. Biosurfactant production by bacteria requires carbon nutrients, one of which is a sugar substrate.

The use of agricultural waste as a supplier of carbon sources in the form of sugar substrates as a result of hydrolysis has not been further exposed. The results of hydrolysis of agricultural waste can be used as a medium for biosurfactant production. Organic material in organic waste is a source of micronutrients (Wahyono 2011). The use of agricultural waste has been groundbreaking as an alternative material for biosurfactant production. Utilization of agricultural wastes (barley bran, trimming vine shoots, corn cobs, and Eucalyptus globulus chips) for biosurfactant production by bacteria have been done to reduce production costs (Moldes et al. 2007). Rice straw decomposing also has been successfully used for biosurfactant production by Pseudomonas aeruginosa BSZ-07 (Quizhuo et al. 2008).
One of agricultural waste that can produce hydrolyzing sugar is rice straw. According to the Indonesian Center for Rice Research, in the East Java region for March 2018, rice yields reached 2,026,739 tons (BB Padi 2018) and produced 12-15 tons per hectare of rice straw. Rice straw contains polysaccharides in lignocellulose. Lignocellulose is an abundant material, renewable resources, and less attention (Peralta et al. 2012). In rice straw, lignocellulose contains $32 \%$ cellulose, $24 \%$ hemicellulose, and $14 \%$ lignin (Chandel et al. 2007 in Novalina, 2014). Rice straw also produces $40-43 \%$ of carbons. The high cellulose and hemicellulose content can be used as a result of hydrolysis of rice straw and carbon for biosurfactant-producing bacteria. In this study, Penicillium sp. H9 was used to hydrolysis rice straw and its hydrolysis product called rice straw hydrolysis product (RSHP) was used as substrate for biosurfactant production.

Indonesia has a diversity of microorganisms that have the potential to be explored, one of which is a group of bacteria. Hydrocarbonoclastic bacteria in oil sludge are known to produce biosurfactants. Biosurfactant production by indigenous or soil bacteria has been carried out (Amani et al. 2011; Ni'matuzahroh et al. 2017; Lee et al. 2018). This study reveals the ability of indigenous bacteria to grow and produce biosurfactant and knowing the prospect of utilizing RSHP for alternative substrate for biosurfactant production. 


\section{MATERIALS AND METHODS}

\section{Procedures}

Sample collection and bacteria isolation

Oil sludge was obtained from PT. Pertamina, Balongan, West Java, Indonesia. Ten grams of the oil sludge was added to $250 \mathrm{~mL}$ Erlenmeyer flasks containing $90 \mathrm{~mL}$ distilled water and homogenized with a shaker for 15 minutes. One $\mathrm{mL}$ of supernatants were put into a sterile Petri dish and then added $15 \mathrm{~mL}$ of Nutrient Agar. This Petri dish was incubated at $30^{\circ} \mathrm{C}$ for 24 hours on incubator. The bacteria isolates that have been obtained then characterized and purified.

\section{Morphological and physiological characterization of bacteria}

All isolated bacteria were characterized macroscopically, microscopically, and physiologically. Macroscopic characterization was observed by the morphological colony of form, color, elevation, edges, and consistency. Microscopic observation of the isolates was performed before 18 hours and after 24 hours to make sure the shape and the presence of Gram. Bacteria biochemical test was using Microbact Kit GNB 12A and 12B according to the protocol. Almost bacteria identified were included in the Gram-positive bacteria groups so that the species name was compared to the Bergey's Manual of Determinative Bacteriology 9th and Cowan and Steel's Manual for Identification of Medical Bacteria Third Edition.

\section{Hydrolysis of rice straw by Penicillium sp.H9}

The hydrolysis process was carried out enzymatically by Penicillium sp. H9, a microbial collection of Microbiology Laboratory of Universitas Airlangga which was obtained from Alas Purwo National Park. Organic agriculture waste, rice straw, was dried for two days to reduce the water content then delignified mechanically by the grinding process. Rice straw powder and dilute $\mathrm{NaOH}$ were mixed in a solid-liquid (1:10) for 60 minutes at $100^{\circ} \mathrm{C}$. The mixture was cooled to room temperature and washed to $\mathrm{pH} 7.0$ with distilled water then dried to remove the water. Two gram of pretreatment rice straw was added to $100 \mathrm{~mL}$ media Mendel-Sternberg's and autoclaved at $121^{\circ} \mathrm{C}$ for 15 minutes. The media was cooled to room temperature and added $4 \%(\mathrm{v} / \mathrm{v})$ spores suspension of Penicillium sp. H9 then incubated at shaker incubator for 6 days. Sample was filtrated through sterile filter unit (Minisart NML syringe filter $0.2 \mu \mathrm{m}$ ). The final filtrate was served as RSHP in the following experiments. The reducing sugar content was measured by the Somogyi-Nelson method.

\section{Biosurfactant production}

Media Synthetic mineral water used for biosurfactant production in this study was modified from Pruthi and Cameotra (1997). The composition of medium was the following (g/L): $\left(\mathrm{NH}_{4}\right)_{2} \mathrm{SO}_{4}(3.0 \mathrm{~g} / \mathrm{L}), \quad \mathrm{NaCl}(10 \mathrm{~g} / \mathrm{L})$, $\mathrm{MgSO}_{4} .7 \mathrm{H}_{2} \mathrm{O} \quad(0.2 \mathrm{~g} / \mathrm{L}), \quad \mathrm{CaCl}_{2} \quad(0.01 \mathrm{~g} / \mathrm{L}), \quad \mathrm{MnSO}_{4} \cdot \mathrm{H}_{2} \mathrm{O}$ $(0.001 \mathrm{~g} / \mathrm{L}), \mathrm{H}_{3} \mathrm{BO}_{3}(0.001 \mathrm{~g} / \mathrm{L}), \mathrm{ZnSO}_{4} .7 \mathrm{H}_{2} \mathrm{O}(0.001 \mathrm{~g} / \mathrm{L})$, $\mathrm{CuSO}_{4} .5 \mathrm{H}_{2} \mathrm{O}(0.001 \mathrm{~g} / \mathrm{L}), \mathrm{CoCl}_{2} .6 \mathrm{H}_{2} \mathrm{O} \quad(0.005 \mathrm{~g} / \mathrm{L})$ dan $\mathrm{NaMoO}_{4} \cdot 2 \mathrm{H}_{2} \mathrm{O}(0,001 \mathrm{~g} / \mathrm{L})$. AMS buffer consists of $(\mathrm{g} / 50 \mathrm{~mL}): \mathrm{KH}_{2} \mathrm{PO}_{4}(5 \mathrm{~g}), \mathrm{K}_{2} \mathrm{HPO}_{4}(2.62047 \mathrm{~g})$ and $\mathrm{Fe}$ $(\mathrm{g} / 50 \mathrm{~mL}) \mathrm{Fe}_{3} \mathrm{O}_{4}(0.0006 \mathrm{~g})$. The total culture volume was $20 \mathrm{~mL}$ and added 1.5 mLof rice straw sugar hydrolysis with the concentration $209.3 \mathrm{ppm}$. 2\% (v/v) bacteria suspension was used for the culture. Microbial culture was incubated for $0,1,3$, and 5 days in a rotary shaker $120 \mathrm{rpm}$ at room temperature.

\section{Detection of growth and biosurfactant product}

Bacteria cultures that incubated during the incubation time were measured for TPC, surface tension (ST), and emulsification activity (EA). Samples of culture medium were centrifuged for 15 minutes at $6000 \mathrm{rpm} .10 \mathrm{ml}$ supernatants were taken for surface tension analysis using Tensiometer Du-Nuoy, Surface tension value was stated in $\mathrm{mN} / \mathrm{m}$ or dyne/cm. The emulsification activity was obtained from $1 \mathrm{ml}$ of supernatant which added by $1 \mathrm{ml}$ of kerosene, the mixture was homogenized with vortex for 2 minutes, and the emulsification activity can be observed after 1 hour and 24 hours.

\section{RESULTS AND DISCUSSION}

\section{Morphological and microscopical characteristics of bacteria}

Six morphologically distinct bacteria colonies were isolated from Balongan's oil sludge. Isolates were identified macroscopically, microscopically, and physiologically. Macroscopic and microscopic characters are presented in table 1.

Every colony displayed different characters (Figure 1), but microscopic characters of some bacteria showed the similarity of characters. Only one bacterium has rod-shaped and Gram-negative, BP (1) 6 isolates, and other bacteria were identified with rod-shaped and Gram-positive (Figure 2). Isolate BP (1) 4 have a longer rod-shaped compared with the others.

Table 1. Macroscopic and microscopic characters of oil sludge indigenous bacteria from Balongan

\begin{tabular}{|c|c|c|c|c|c|c|c|}
\hline \multirow{2}{*}{ Isolates } & \multicolumn{5}{|c|}{ Macroscopic characters of colony } & \multicolumn{2}{|c|}{ Microscopic characters of cell } \\
\hline & Color & Elevation & Edge & Shape & Consistency & Shape & Gram \\
\hline BP (1) 1 & White & Raised & Entire & Circular & Opaque & Rod & Positive \\
\hline BP (1) 3 & White yellowish & Raised & Entire & Circular & Opaque & Rod & Positive \\
\hline $\mathrm{BP}(1) 4$ & White & Flat & Undulate & Irregular & Translucent & Rod & Positive \\
\hline $\mathrm{BP}$ (1) 5 & White & Flat & Entire & Circular & Transparent & Rod & Positive \\
\hline $\mathrm{BP}(1) 6$ & White Bone & Flat & Undulate & Irregular & Translucent & Rod & Negative \\
\hline BP (1) 8 & Orange & Flat & Entire & Circular & Transparent & Rod & Positive \\
\hline
\end{tabular}



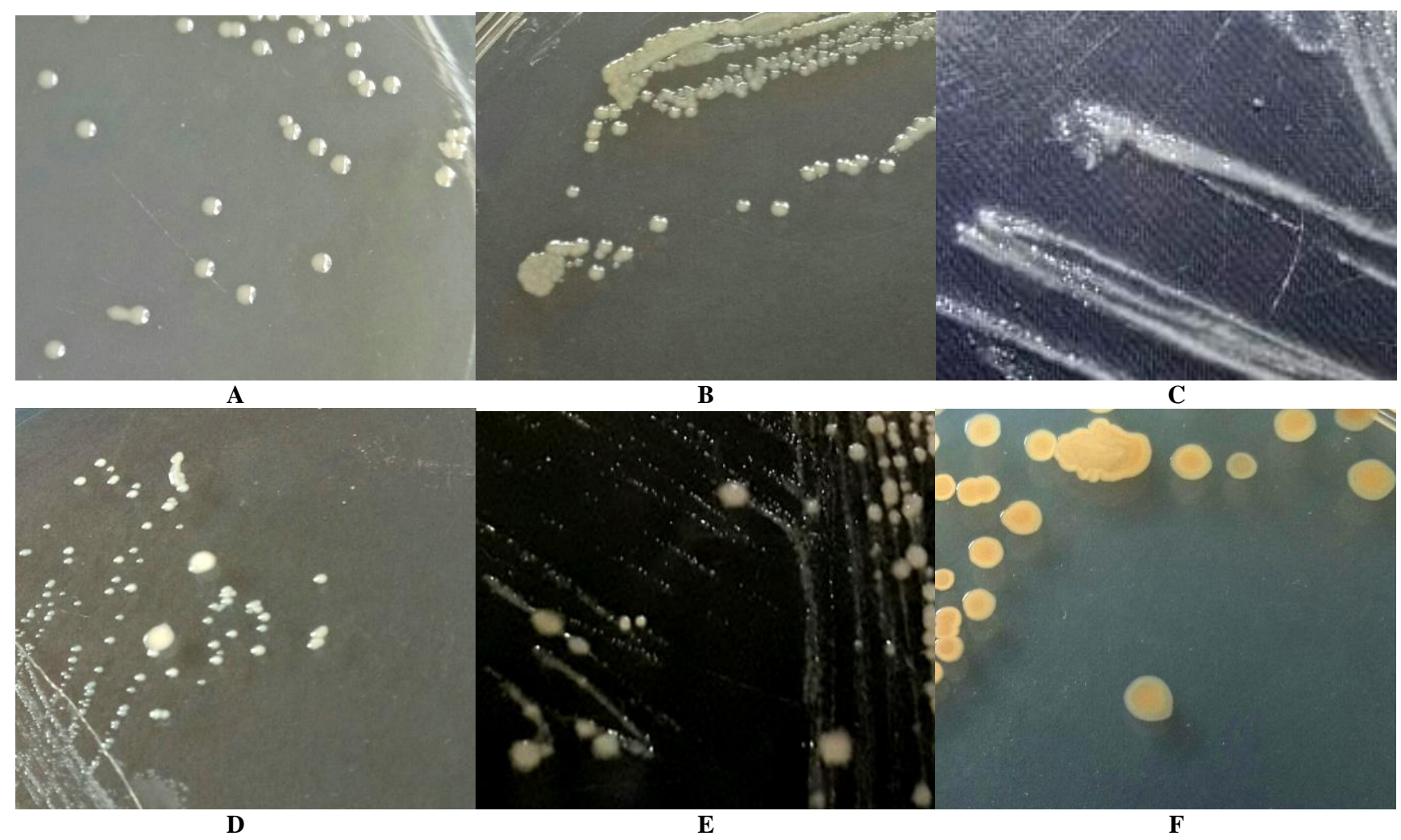

Figure 1. Macroscopic morphology of indigenous bacteria from Balongan's oil sludge. A is isolate of BP (1) 1; B is isolate of BP (1) 3; $\mathrm{C}$ is isolate of BP (1) 4; D is isolate of BP (1) 5; E is isolate of BP (1) 6 ; and F is isolate of BP (1) 8

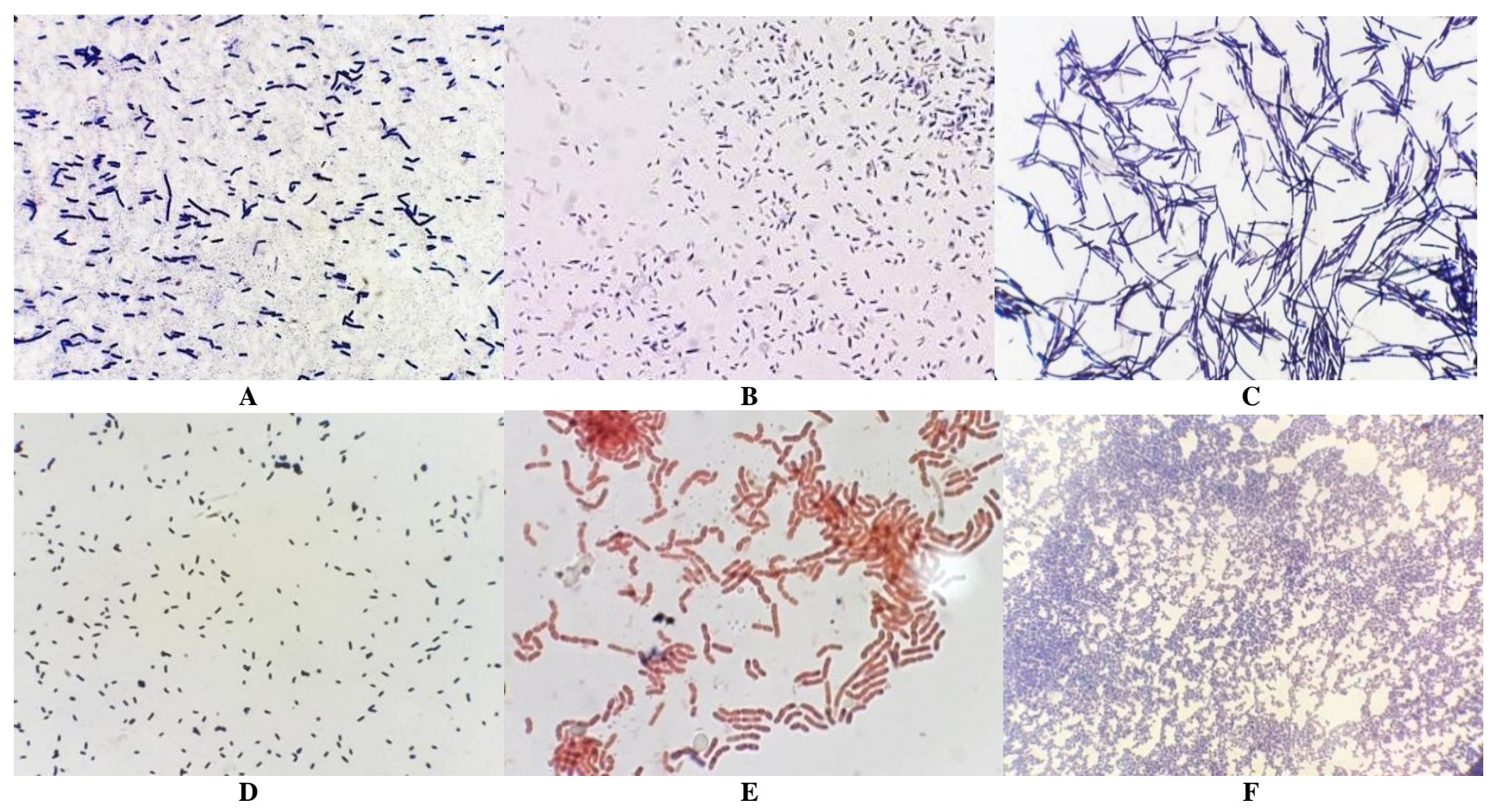

Figure 2. Cell of indigenous bacteria from Balongan's oil sludge. A. Isolate of BP (1) 1; B. Isolate of BP (1) 3; C. Isolate of BP (1) 4; D. Isolate of BP (1) 5; E. Isolate of BP (1) 6; and F is isolate of BP (1) 8 


\section{Physiological characteristic of bacteria}

Based on differences in microscopic and macroscopic character, physiological characteristics were carried out to obtain the genus name. The physiological test of the bacteria is shown in Table 2 .

According to Jaccard's index (Real et al. 1996), the isolates were identified using similarity index $(\mathrm{J})$ values. The isolates were identified as Propionobacterium sp. (isolate BP (1) 1) $(\mathrm{J}=60 \%)$, Propionobacterium sp. (isolate BP (1) 3) $(\mathrm{J}=60 \%)$, Bacillus sp. (isolate BP (1) 4) $(\mathrm{J}=80 \%)$, Corynebacterium sp. (isolate BP (1) 5$)(\mathrm{J}=$ $75 \%)$, Rothia sp. (isolate BP (1) 6) $(\mathrm{J}=75 \%)$, and Corynebacterium sp. (isolate BP (1) 8) $(\mathrm{J}=51 \%)$.

\section{Biosurfactant production}

All isolated bacteria were able to grow and produce biosurfactants when grown on synthetic mineral water containing RSHP as the main carbon. This is evidenced by the growth response shown by the TPC are and the decrease in ST of the supernatant culture which indicates the production of biosurfactant. Value of TPC and ST are displayed in figure 2 .

Growth response of bacteria had formed after first-day incubation and increased continuously until the end of the incubation. This data shows that the addition of RSHP as a carbon source can be used by indigenous bacteria to grow. Biosurfactant production of isolates BP (1) 1, BP (1) 3, and BP (1) 5 tends increased from the first day of incubation to the end of incubation where all three bacteria are in the exponential phase.
Table 2. The biochemical test of bacteria using microbact GNB $12 \mathrm{~A}$ and $12 \mathrm{~B}$

\begin{tabular}{|c|c|c|c|c|c|c|}
\hline \multirow{2}{*}{ Type of test } & \multicolumn{6}{|c|}{ Bacteria isolate code } \\
\hline & 1 & 3 & 4 & 5 & 6 & 8 \\
\hline Oxidase & + & + & + & + & + & + \\
\hline Motility & - & - & - & - & - & - \\
\hline Nitrate & + & + & - & + & - & - \\
\hline Lysine & - & + & + & + & + & - \\
\hline Ornithine & - & - & - & - & - & - \\
\hline $\mathrm{H} 2 \mathrm{~S}$ & - & - & - & - & - & - \\
\hline Glucose & - & - & + & - & - & - \\
\hline Mannitol & - & - & - & - & - & - \\
\hline Xylose & - & - & + & - & - & - \\
\hline ONPG & - & - & - & - & - & - \\
\hline Indole & - & - & - & - & - & - \\
\hline Urease & + & - & - & - & - & - \\
\hline VP & - & - & - & - & - & - \\
\hline Citrate & - & + & - & + & + & - \\
\hline TDA & - & - & - & - & - & - \\
\hline Gelatin & - & - & - & - & - & - \\
\hline Malonate & - & - & - & - & + & - \\
\hline Inositol & - & - & - & - & - & - \\
\hline Sorbitol & - & - & - & - & - & - \\
\hline Rhamnose & - & - & - & - & - & - \\
\hline Sucrose & - & - & - & - & - & - \\
\hline Lactose & - & - & - & - & - & - \\
\hline Arabinose & - & - & - & - & - & - \\
\hline Adonitol & - & - & - & - & - & - \\
\hline Raffinose & - & - & - & - & - & - \\
\hline Salicin & - & - & - & - & - & - \\
\hline Catalase & + & + & + & + & + & + \\
\hline \multicolumn{7}{|l|}{ Arginine } \\
\hline After 24 hours & - & - & - & - & - & - \\
\hline After 48 hours & - & - & - & - & - & - \\
\hline
\end{tabular}
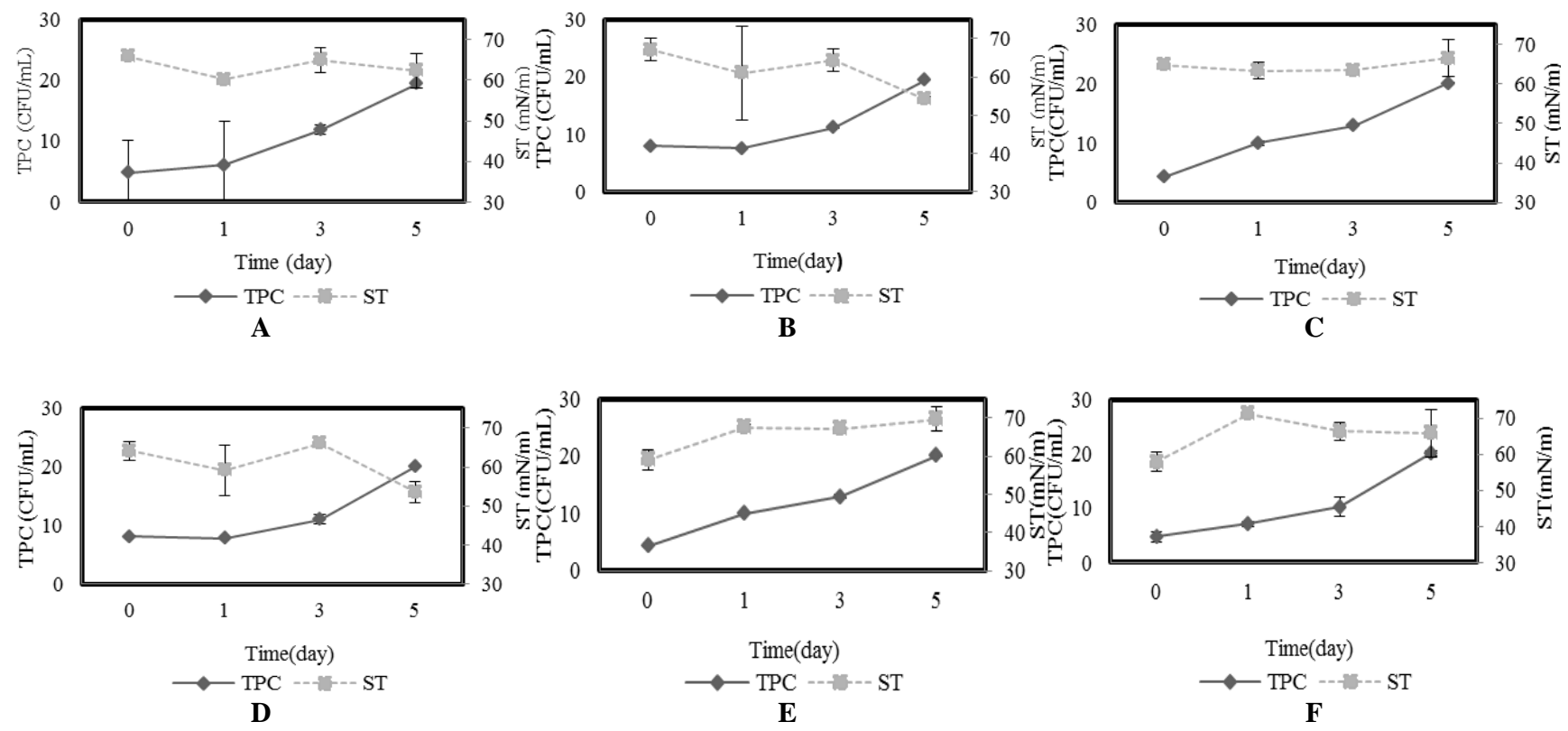

Figure 2. Total Plate Count and Surface Tension result of culture supernatant during $0,1,3$ and 5 days incubation by: A. Propionibacterium sp. BP (1) 1; B. Propionibacterium sp. BP (1) 3; C. Bacillus sp. BP (1) 4; D. Corynebacterium sp. BP (1) 5; E. Rothia BP (1) 6; F. Corynebacterium sp. BP (1) 8 was using RSHP as carbon source 
Table 3. Growth rate, generation time, TPC and ST result in fifth day incubation time

\begin{tabular}{lcccc}
\hline Isolates & $\begin{array}{c}\text { Growth rate } \\
\text { (cell/hour) }\end{array}$ & $\begin{array}{c}\text { Generation } \\
\text { time (hour) }\end{array}$ & $\begin{array}{c}\text { TPC } \\
\text { (CFU/mL) }\end{array}$ & $\begin{array}{c}\text { ST } \\
\text { (mN/m) }\end{array}$ \\
\hline BP (1) 1 & 0.41 & 2.47 & $19.42 \pm 0.02$ & $62.30 \pm 4.31$ \\
BP (1) 3 & 0.32 & 3.15 & $19.48 \pm 0.02$ & $54.15 \pm 0.60$ \\
BP (1) 4 & 0.44 & 2.28 & $20.12 \pm 0.05$ & $66.52 \pm 4.61$ \\
BP (1) 5 & 0.33 & 3.03 & $20.07 \pm 0.04$ & $53.56 \pm 2.66$ \\
BP (1) 6 & 0.44 & 2.30 & $20.08 \pm 0.02$ & $69.72 \pm 3.09$ \\
BP (1) 8 & 0.43 & 2.34 & $20.22 \pm 0.46$ & $65.80 \pm 6.62$ \\
\hline
\end{tabular}

The highest biosurfactant production was obtained on the fifth-day incubation by isolate BP (1) 5 with a surface tension value of $53.56 \pm 2.66 \mathrm{mN} / \mathrm{m}$ and $54.15 \pm 0.60$ $\mathrm{mN} / \mathrm{m}$. The pattern of biosurfactant production by BP (1) 5 and BP (1) 3 shows that bacterial growth is in line with the quantity of biosurfactant product. The high value of surface tension is in line with the result of TPC values, but inversely proportional to the generation time of bacteria. Isolate BP (1) 5 takes 0.61 hours to replicate while isolates with the highest generation time only need 0.46 hours to replicate (Table 3 ).

\section{Discussion}

All isolated bacteria from Balongan's oil sludge were identified into four genera as Propionibacterium sp., Bacillus sp., Corynebacterium sp., and Rothia sp.based on the results of physiological tests using microbact $12 \mathrm{~A}$ and 12B. Four genera were able to grow and produced biosurfactants when grown on sugar hydrolysis of rice straw. Generally, the type of biosurfactant produced by Propionibacterium sp., Bacillus sp., Corynebacterium sp., and Rothia sp have potential in the process of hydrocarbon degradation. Several studies have reported similar results where the bacterial isolated from hydrocarbon contaminated areas was obtained Bacillus, Corynebacterium, Propionibacterium, and Rothia (Calvo et al. 2004; Sette et al. 2007; Sathishkumar et al. 2008; Yang et al. 2017). Bacillus produced surfactin, the type of biosurfactant which capable to emulsify the hydrocarbon. In addition, biosurfactant also has the potential as antimicrobial agents and inhibitors biofilm formation. The lipopeptide, biosurfactant types produced by Bacillus sp. strain SW9 that was capable of inhibiting biofilm formation in a wide range of bacteria. While, lipopeptide produced by Propionibacterium freudenreichii was known to inhibit Pseudomonas aeruginosa biofilm production (Wu et al. 2013; Hajfarajollah et al. 2014). The ability to inhibit biofilm formation is owned by Corixyn, the type of biosurfactant, produced by Corynebacterium xerosis strain NS. This biosurfactant disrupted biofilm preform of $S$. aureus, $S$. mutans, $P$. aeruginosa, and $E$. coli beside of that, it is also reported this ability as an anti-microbial agent (Dalili et al. 2015). Meanwhile, the type of biosurfactant from the genus Rothia has not been reported.

All of indigenous bacteria from oil sludge were able to grow and produce biosurfactant in RSHP. Reducing sugar in hydrolysate of rice straw has the following composition of $41-43 \%$ glucose, $14.8-20.2 \%$ xylose, $2.7-4.5 \%$ arabinose, $1.8 \%$ mannose, and $0.4 \%$ galactose (Maiorella 1985; Roberto et al. 2003). Biosurfactant production associated with growth response has been reported for isolate AB-Cr1, where the bacterial growth showed a parallel relationship with biosurfactant production and correlated with the glucose utilization (Ruzniza 2005). The result of this study is similar to Mulligan and Gibbs (1993), biosurfactant compound was a bacterial bioproduct produced during exponential and stationer phases. Biosurfactant production was found parallel to the highest reduction of surface tension which observed during the exponential growth of bacteria (Ruzniza 2005).

Six indigenous bacteria can grow and produce biosurfactants in the RSHP. The most potential isolate was Corynebacterium BP (1) 5 with TPC value of 20.07 $\mathrm{CFU} / \mathrm{mL}$ and $\mathrm{ST}$ value of $53.56 \mathrm{mN} / \mathrm{m}$. RSHP have the prospect to be an alternative substrate for biosurfactant production. Moreover, utilization of RSHP can reduce organic waste in the environment.

\section{ACKNOWLEDGEMENTS}

Authors would like to thank Faculty of Science and Technology, Universitas Airlangga, Surabaya, Indonesia which has funded the research through the Penelitian Unggulan Fakultas grant scheme in 2018 and Suwarni for his aid during this research.

\section{REFERENCES}

Amani H, Haghighi M, Sarrafzadeh MH, Mehrnia MR, Shahmirzaee F. 2011. Optimization of the production of biosurfactant from Iranian indigenous bacteria or the reduction of surface tension and enhanced oil recovery. Petroleum Sci Technol 29: 301-311.

BB Padi. 2018. Luas Panen Padi di beberapa Wilayah. Balai Besar Penelitian Tanaman Padi, Subang. http://bbpadi.litbang.pertanian.go.id.

Barrow GI, Feltham RKA. 1993. Cowan and Steel's Manual for Identification of Medical Bacteria. 3rd ed. Cambridge University Press, UK.

Bergey DH, Holt JG. 1994. Bergey's Manual of Determinative Bacteriology. William \& Wilkins. Baltimore.

Calvo C, Toledo FL, González-López J. 2004. Surfactant activity of a naphthalene degrading Bacillus pumilus strain isolated from oil sludge. J Biotechnol 109 (3): 255-262.

Dalili D, Amini M., Faramarzi MA, Fazeli MR, Khoshayand MR, Samadi N. 2015. Isolation and structural characterization of Coryxin, a novel cyclic lipopeptide from Corynebacterium xerosis NS5 having emulsifying and anti-biofilm activity. Colloids and Surfaces B: Biointerfaces 135: 425-432.

Elazzazy AM, Abdelmoneim TS, Almaghrabi OA. 2015. Isolation and characterization of biosurfactant production under extreme environmental conditions by alkali-halo-thermophilic bacteria from Saudi Arabia. Saudi J Biol Sci 22: 466-475.

Hajfarajollah H, Mokhtarani B, Noghabi KA. 2014. Newly antibacteria and antiadhesive lipopeptide biosurfactant secreted by a probiotic strain, Propionibacterium freudenreichii. Appl Biochem Biotechnol 174: 2725-2740.

Real R, Vargas J M. 1996. The probabilistic basis of Jaccard's index of similarity. Syst Biol 45 (3): 380-385.

Kosaric N. 1993. Biosurfactants: Production, Properties, Application. Marcel Dekker. Inc, New York.

Maiorella BL. Ethanol. In: Young M, editor. 1985. Comprehensive Biotechnology, Vol. 3. Pergamon Press, Oxford. 
Moldes AB, Torrado AM, Barral MT, Domiänguez JM. 2007. Evaluation of biosurfactant production from various agricultural residues by Lactobacilluspentosus. J Agric Food Chem 55: 4481-4486.

Mulligan CN and Gibbs BF. 1993. Factors influencing the economics of biosurfactant. In: Cosaric N (ed.). Biosurfactant Production, Properties, and Application. Marcel Dekker Inc. New York

Ni'matuzahroh, Yuliawatin ET, Kumalasari DP, Trikurniadewi N, Pratiwi IA, Salamun, Fatimah, Sumarsih S, Yuliani H, 2017. Potency of Oil Sludge Indigenous Bacteria from Dumai-Riau in Producing Biosurfactant on Variation of Saccharide Substrates. Proceeding of International Conference on Green Technology 8: 339-340.

Novalina I. 2014.Hydrolysis Enzymatic of Rice Straw by Penicillium $\mathrm{sp}$ $\mathrm{H} 9$ on Variation of $\mathrm{pH}$ and Temperature. [Thesis]. Universitas Airlangga, Surabaya. [Indonesian].

Peralta-Yahya PP, Zhang F, del Cardayre SB, Keasling JD. 2012. Microbial engineering for the production of advanced biofuels. Nature 488: 320-328.

Pruthi V, Cameotra. 1997. Rapid identification of biosurfactant producing bacterial strain using cell surface hydrophobicity techniques. Biotechnol Tech. 11: 671-674.

Qiuzhuo Z, Weimin C, Juan W. 2008. Stimulatory effects of biosurfactant produced by Pseudomonas aeruginosa BSZ-07 on rice straw decomposing. J Environ Sci 20: 975-980.

Roberto IC, Mussatto SI, Rodrigues RCLB. 2003. Dilute-acid hydrolysis for optimization of xylose recovery from rice straw in a semi-pilo reactor. Industr Crops Prod 7 (3):171-176.
Ruzniza, Binti Mohd Zawawi. 2005. Production of Biosurfactant by Locally Isolated Bacteria from Petrochemical Waste. [Thesis]. Faculty of Science. Universiti Teknologi Malaysia. [Malaysian]

Sathishkumar M, Binupriya AR, Baik, SH, Yun SE. 2008. Biodegradation of crude oil by individual bacterial strains and a mixed bacterial consortium isolated from hydrocarbon contaminated areas. CLEANSoil, Air, Water 36 (1): 92-96.

Sette LD, Simioni KC, Vasconcellos SP, Dussan LJ, Neto EV, Oliveira VM. 2007. Analysis of the composition of bacterial communities in oil reservoirs from a southern offshore Brazilian basin. Antonie Van Leeuwenhoek 91 (3): 253-266.

Wahyono S. 2011. Pengolahan Sampah dan Aspek Sanitasi. Jurnal Teknologi Lingkungan 2: 113-118. [Indonesian]

Lee DW, Lee H, Kwon BO, Khim JS, Yim UH, Kim BS, Kim JJ. 2018. Biosurfactant-assisted bioremediation of crude oil by indigenous bacteria isolated from Taean beach sediment. Environ Pollut 241: 254-64.

Wu ZY, Ye CS, Guo F, Zhang SH, Yu X. 2013. Evidence for BroadSpectrum Biofilm Inhibition by the Bacterium Bacillus sp Strain SW9. Appl Environ Microbiol 79:1735-1738.

Yang Q, Zhao H, Du B. 2017. Bacteria and bacteriophage communities in bulking and non-bulking activated sludge in full-scale municipal wastewater treatment systems. Biochem Eng J 119: 101-111. 